\title{
The Importance of the Board-President Relationship in Three Community Colleges
}

\author{
JOHN S. LEVIN ${ }^{*}$
}

\section{ABSTRACT}

Governance and management in institutions of higher education have attracted considerable attention in the North American literature. While much has been published concerning the respective roles of the president and the governing board in managing the affairs of colleges and universities, limited attention has been given to the relationship which exists between the two parties. The purpose of this study is to examine the board-president relationship in the academic institution in order to discern reasons for the importance of the relationship. The investigation uses qualitative-interpretive research methods in an examination of three colleges in the province of British Columbia.

Five major conclusions are presented to indicate reasons for the importance of the board-president relationship. First, at the three colleges, the board and the president see themselves as having influence and impact upon the external community. Second, at the three colleges, the board and the president see themselves as having influence and impact upon the internal college community. Third, there is a high level of value compatibility among board members and the president, based on the accounts of the parties. Fourth, board and president together view themselves as the chief authorities of the institution, responsible for the governance and management of the operations of their colleges. And fifth, at the three colleges, board and president together, in their expressed attitudes and actions, mirror perceived characteristics of the larger organization.

\section{RÉSUMÉ}

Les méthodes de gestion et d'administration des établissements d'enseignement supérieur ont suscité un grand intérêt dans les revues spécialisées nordaméricaines. Mais tandis qu'on a publié un grand nombre d'études sur les rôles

* North Island College, Port Alberni, B.C. 
respectifs $d u$ président et du conseil d'administration dans la gestion des affaires au sein des collèges et des universités, bien peu a été dit sur le lien qui existe entre ces deux interlocuteurs. Le but de cette étude est d'examiner les modalités de la relation conseil-président telles qu'elles existent dans les établissements d'enseignement supérieur afin d'établir ce qui fait qu'elles sont si importantes. Cette recherche se fonde sur des méthodes qualitatives et interprétatives appliquées à trois collèges de Colombie-Britannique.

Cette enquête a permis de tirer cinq conclusions qui montrent toutes l'importance de la relation conseil-président. Premièrement, dans les trois collèges considérés, le conseil d'administration et le président se croient l'un et l'autre capables d'influencer la communauté à laquelle s'adresse le collège, et d'agir sur elle. Deuxièmement, ils se croient l'un et l'autre capables d'influer et d'agir sur les membres de l'établissement. Troisièmement, si l'on se fonde sur ce qu'en disent les deux parties, on peut voir que les valeurs de l'une et de l'autre vont pour une grande part dans le même sens. Quatrièmement, le conseil et le président se voient comme les deux principaux responsables de la gestion et de l'administration de leur collège. Enfin, dans les trois collèges, le conseil d'administration et le président illustrent, par leur attitude et leurs actes, les caractéristiques manifestes de l'organisation collégiale dans son ensemble.

\section{Rationale and Purpose}

The importance of the board-president relationship in the North American academic institution is neither disputed nor in doubt based upon the assertions of scholars and practitioners. While the reasons for its importance may seem self-evident, there has been no attempt to examine the relationship, systematically, in order to formulate reasons for its importance. It is surprising that there is a lack of explanation for a relationship which both commands considerable attention and attracts judgement in higher education. Whereas some observers (Munitz, 1980; Pappas \& Ritter, 1983; Wood, 1984; Gleazer Jr., 1985) are concerned with problems, conflicts, and tensions in the boardpresident relationship, others emphasize that the importance of the relationship can be seen in its effects on each of the separate parties, presidents (Kauffman, 1980; Fisher, 1984; Vaughan, 1986) and board members (Richardson Jr. et al, 1972; Corson, 1980; Gleazer Jr., 1985). Nevertheless, although assertions of the importance of board-president relationship are universal in discussions of community colleges, four-year colleges, and universities in North America, no clear, compelling, or authoritative explanation of how board members and presidents work together is to be found in higher education scholarship. 
Governance and management in institutions of higher education have assumed prominent positions, especially in recent decades (Corson, 1975; Baldridge et al, 1977; Mortimer \& McConnell, 1978; Clark, 1983; Keller, 1983; Lee \& Van Horn, 1983; Cameron, 1984; Dill, 1984; Alfred \& Smydra, 1985; Birnbaum, 1988). While much has been published concerning the respective roles of the president and the governing board in managing the affairs of colleges and universities, limited attention has been given to the relationship which exists between the two parties. The importance of the relationship is acknowledged, but no systematic research has justified the claim.

\section{The Study}

This study reports an examination of the board-president relationship in three community colleges in the province of British Columbia (Canada). This examination discerns reasons for the importance of the relationship by identifying determinants and effects of the relationship, dominant characteristics of the relationship, and approaches, patterns of behaviour, and rationales of the parties in governing and managing the academic institution.

\section{The Importance of the Board-President Relationship}

Five principal reasons are uncovered for justifying the importance of the boardpresident relationship. Board and president, together, have influence upon the external environment by establishing or maintaining an association between their college and local communities, by improving the reputation of the college for government officials and community members, by providing specific services to the local communities, and by developing an image of the college as a particular kind of institution. Second, board and president, together, affect internal college constituents and interest groups by improving the level of trust among and between various college groups through a reduction of conflict and visible friction within the college, by sustaining both broad participation of constituents in college governance and a high level of verbal interaction among college constituents, and by maintaining the philosophy of the college embraced by college constituents. Third, there is a high degree of consistency between the official values of the institution and those expressed by board members and the president. Board and president, together, act in accord with established and articulated goals of their college. Fourth, how the college is governed and managed and the outcomes of these processes are attributable to both parties and how they work together. Board and president, together, are not only influences in institutional governance and management but also the parties responsible, the chief authorities. And fifth, board and president, together, share 
and reinforce the philosophy and values of their college. The way in which the parties work together is consistent with the orientation associated with the larger organization: the relationship is, in part, a microcosm of the college.

\section{The Research: Framework, Design, and Procedures}

A review of the literature on governing boards and presidents indicates that, while there is much discussion of the relationship, there is as yet no systematic study of either its nature (i.e., determinants, effects, and characteristics) or the reasons for its importance. Nonetheless, the literature does suggest at least three distinct categories for conceptualizing the relationship. These categories are usefully viewed as three dimensions of the board-president relationship: a formal or legal dimension, an operational or working dimension, and a personal or human dimension.

The formal dimension of the relationship pertains to the prescriptions and expectations for the two parties. These include the duties, responsibilities, functions, and norms of behaviour found in such documents as government legislation, institutional charters and policies, guidebooks, and legal contracts. For example, boards are seen to have responsibility for policy matters and presidents for administration (Corson, 1975: Ingram, 1979; Fisher, 1984). These prescriptions and expectations are derived from a broad concept of law (Kaplin, 1985), and the conception of the relationship is fundamentally of a role relationship, one which serves both to control and to predict the behaviours of the two parties.

What the parties actually do, however, is not necessarily consistent with the prescriptions and expectations either found in legalistic documents or expressed by practitioners and scholars alike. Thus, a second conception of the relationship addresses the behaviours and actions of the parties, based upon observations and inferences derived from the two parties' joint involvement in the operations of the institution. Behaviours and actions may depend upon such variables as an institution's governance pattern or structure (Kerr \& Gade, 1986), the style of the president (Kerr \& Gade, 1986), the operating style of the board (Wood, 1985), and external pressures upon the institution (Wood, 1984).

A third conception of the relationship arises through the personal and interpersonal experiences of board members and presidents in working together. In this conception, the board-president relationship has a personal dimension formed out of the perceptions and evaluations of the two parties in their interactions with each other. Personal preferences, personality dynamics, and interpersonal interactions influence perceptions and judgements (Wood, 1985); background characteristics and specific interests of board members (Gleazer Jr., 
1985 ) and the personal style of the president (Kerr \& Gade, 1986) influence how the parties view and evaluate each other; and such qualities as trust and respect among a president and board members influence relations between the parties (Ingram, 1979).

Each dimension provides a perspective of only a partial conception of the relationship. Together, the three dimensions constitute a comprehensive conception of the board-president relationship, and this conception was used to establish a research framework for an investigation of a setting or settings (i.e., three community colleges) to explore the nature of the board-president relationship, then to examine how boards and presidents jointly govern and manage the academic institution, and finally to discern why the relationship is deemed to be important.

The investigation required information which included both documentary and perceptual descriptions of the relationship. Research questions developed were of two kinds, those relating to documentary evidence (e.g., government legislation, institutional policies) and those relating to perceptions (i.e., those of board members and presidents). Data collection and analysis were consistent with current scholarship on research methods referred to as qualitativeinterpretive (Hammersley \& Atkinson, 1983; Smith, 1983; Goetz \& Le Compte, 1984; Miles \& Huberman, 1984; Popkewitz, 1984; Burgess, 1985; Erickson, 1986; Merriam, 1988). The investigation focussed upon the meaning the participants (i.e., board members and presidents) attributed to their actions, attitudes, and situations, examined the institutional context in which the parties acted, and noted the context which formalized the relationship (e.g., government legislation).

Three community colleges in the province of British Columbia were chosen as sites (comprising one case) for research investigation, and three college presidents and twenty-four governing board members (out of a total of twentysix at the three colleges) were interviewed during 1988. Colleges were chosen from two distinct geographical regions. Each college was given a fictitious name in order to preserve the anonymity of the participants in the relationship, as agreed upon at the initiation of the investigation. The three colleges were named Appletree College, Oak College, and Cedar College respectively. Data collected and analyzed from the three institutions included institutional documents, (such as college calendars, collective agreements, institutional plans, board policy documents, administrative policy documents, management planning documents, and board meeting minutes for an eight to twelve month period), audio taped interviews of twenty-seven participants, interview summaries verified by the participants, and field notes of observations made 
and recorded by the researcher. Provincial government legislation, which applied to the roles, duties, and responsibilities of governing boards and chief executive officers at community colleges in the province of British Columbia during 1987, was a fifth kind of data collected and analyzed.

\section{The Three Colleges: A British Columbia Context}

The study's findings, presented in a subsequent section of this article, indicate that both historical and developmental factors have a bearing upon the boardpresident relationship in the three colleges. It is appropriate at this point, therefore, to discuss some of these factors. Also, some information on specific conditions at individual colleges, which have a bearing on the board-president relationship, are included in this discussion.

Established by government in the 1960s and 1970s, individual colleges in the province of British Columbia developed as independent institutions, although provincial government influence over these colleges became more pronounced in the late 1970s and 1980s. College development in British Columbia reflects a shift from a community orientation toward provincial interests and priorities (Dennison, 1986). Furthermore, as a result of institutional growth, unionization of faculty and support staff, and changing external conditions (e.g., the provincial government's fiscal restraint program), both formal and informal control over colleges became more centralized, more concentrated in the levels of senior college management, governing board, and provincial government ministry. College management adopted a more presidential and hierarchical character, with, for example, colleges substituting the appellation president for the legislated and traditional one of principal to denote the chief executive officer, and colleges adding levels of management to their organization, including a vice-presidential level either in title or in operational style. By 1983, all governing board members were government appointments as distinct from an earlier period when a combination of government appointments and elected school board representatives formed college boards. Nevertheless, colleges in British Columbia continue to function and develop rather independently. This is evident in their collective bargaining arrangements with separate faculty unions, in the legislation which specifies that college boards are responsible for hiring chief executive officers, and in processes and outcomes of decision-making (e.g., college policies).

The development of the three colleges in this study, Appletree, Oak, and Cedar, began at the end of the 1960s and the beginning of the 1970s. From a broad perspective, these three colleges have many comparable characteristics. Initially, they occupied temporary facilities and experienced 
rapid growth and change. At the time of this study, both the size of the student populations (between 3000 and 4000 full-time equivalency students) and the type of educational programmes (comprising academic, career, vocational, and community offerings) were similar. The presidents of the three colleges were long-time employees of the college, all serving in other administrative positions prior to their move to the presidency. All boards contained members with over three years of experience on the board, and some members had in excess of five years' experience.

The individual histories of the colleges, however, show dissimilarities, particularly when viewed from an internal perspective. Appletree College, for example, faced public embarrassment through the financial transactions of a former president, which were on behalf of the college. His departure from office not long after this episode, and as a consequence of his actions and the board's judgement, demoralized many college employees, in that many had a high regard for his abilities. Oak College evolved as an institution with a pronounced collegial style of governance and an educational focus upon its community. The government's fiscal restraint program of the 1980s, as reported by both board members and the president, frustrated efforts to maintain both this style and this focus. As a result of this restraint program, or in concert with it, labour management relations at Oak College became more formalized and the gulf between senior management and the faculty widened. Under such conditions, the connection between senior management and the board became more firmly cemented. At Cedar College, a pattern of union militancy for nearly a decade was strengthened by government initiatives in the $1980 \mathrm{~s}$. These included changes in legislation and the fiscal restraint program. Moreover, funding restraints and ministry policies attempting to shift control from colleges to government led, according to board members and the president, to a more internally driven mandate for Cedar College. This mandate suggested that, to preserve the value of institutional self-direction and to maintain the quality of educational services at Cedar, a more selective approach to the admission of students would be pursued and that limits would be placed upon the scope of the comprehensive educational programme. Cedar College would become, in the view of the internal constituents, an elite institution.

It is reasonable to assume that both shared histories and common characteristics have comparable effects upon the board-president relationship. It is also reasonable to assume that their distinct histories have unique effects upon the board-president relationship. Nevertheless, as this study is more of a case study of the board-president relationship in one 
province than three separate case studies, synthesis of findings and conclusions underlines commonalities rather than differences among the colleges.

\section{The Three Dimensions of the Board-President Relationship}

\section{The Formal Dimension of the Relationship}

What constitutes the formal dimension of the board-president relationship exists in the perceptions and arrangements of the two parties. Only the separate roles of the two parties are regulated by legislation. Legislated expectations are both narrow and limited, and suggest an unequal partnership. The board has primary authority over the president and over the academic institution (Province of British Columbia, 1984). With the exception of the president's reporting relationship to the board, there are no legislated regulations specified for the board-president relationship itself. At Appletree College, the formal dimension of the relationship is a negligible component of the relationship, and formal matters which impact upon the relationship are limited primarily to a narrow role of the board in the college (e.g., its participation in the collective bargaining process with employee groups). At Oak College, the presence of a formal dimension, while associated with laws and expectations for the roles of both separate parties, also includes institutional policies and practices which regulate and prescribe behaviours of both parties in specific situations (e.g., termination of employment for faculty) and during specific conditions (e.g., labour disputes). Furthermore, the formal dimension of the relationship at Oak College is characterized by the college's connection to government, suggesting that the college is a government institution and that the relationship is in part a political creation. At Cedar College, there is no explicit formal connection of board and president aside from the employer-employee relationship which has effect when the president is hired by the board and ceases with the termination of the president's contract of employment. At Cedar College, there are, however, variations among the participants in how they understand the character and the importance of the formal dimension.

\section{The Operational Dimension of the Relationship}

A distinct operational dimension for the relationship can be identified with each of the three colleges. At Appletree College, two separate parties are involved in the management of a rational hierarchy: the president is the chief executive 
officer of a bureaucracy and the board directs the bureaucracy through the establishment of policy. The board approves and the president acts, or with his senior administrators proposes actions; the board serves as a filter for the president's intentions and actions. Joint activities are not apparent in the boardpresident relationship at Appletree. The president at Appletree is designated as the party responsible for college decisions. At Oak College, board and president share governance and management responsibilities. For example, in the initiation of policy, the president as much as the board is active, and in the actual writing of policy, board members are involved. The parties, with other senior managers, work toward consensus among themselves on both policy and operational decisions. Board and president have achieved agreement on the basic issues of the college's mission, its educational direction, and its response to public information. Their approach to management is characterized by open and informative communication among and between the parties. These understandings and agreements direct how the board and the president manage the operations of the college. At Cedar College, the operational dimension has a dualistic character. Although behaviours are formalized through such documents as college collective agreements with faculty and some board policies, the parties condone actions and prescribed functions of individuals based upon their abilities. In effect, the board delegates responsibilities to the president which are formally theirs, and both board and president accept that specific board members, particularly the board chairperson, and other managers, perform duties usually identified with the president of a college. The parties' working or operational relationship suggests that a formal process, procedures, and regulations may not be necessary in that expectations are clear, projected outcomes are understood, and confidence in individuals is based upon respect for both intelligence and professional experience. The board's operational relationship with the president is largely manifest in the relationship between the board chairperson and the president. And given that these two individuals have a long history of involvement with each other and express both trust and respect for each other, individual expertise may be relied upon as much as role responsibility and authority and valued to a far greater extent.

\section{The Personal Dimension of the Relationship}

At each college, personal relationships among the parties have distinct functions. At Appletree College, personal relationships among the parties can be described as politically oriented: the parties seek allies and support for their interests and attempt to achieve predictability and control in interpersonal 
relationships among the parties. Ultimately these behaviours enhance the leadership role of the president. At Oak College, the personal relationships are described as arenas and opportunities for communication, underlining the value the two parties place in informal discussion. The personal dimension at Oak College involves both trust and respect among the parties. At Cedar College, personal relationships are described by the parties as instrumental, vehicles which connect the board-president relationship to the governance and the management of the college.

\section{Determinants of the Relationship}

Determinants of the board-president relationship can be placed under two broad categories: people and perceptions. People include those individuals such as government officials, externally, and college board members, administrators, and the president, internally, who have influence on how the parties work together. Perceptions include those beliefs, attitudes, and understandings held by individuals or groups which have a bearing on how the parties work together.

At Appletree College, principal determinants of the board-president relationship include the president, the former president, the board chairperson, senior administrators as a group, and the government Minister of Advanced Education. The president is viewed as a caring, supportive, and responsive individual. His treatment of others, his interests and abilities, and his personal associations within the college and external to the college give him influence with the board, and this influence has a major impact on how the two parties work together.

At Oak College, principal determinants include both group dynamics of college participants and the provincial government. Group dynamics which influence how board and president work together include not only those of the board members and the president, but also those of senior administrators and the board, those of faculty, those of board members alone, and those of the board chairperson and the president. These group dynamics are closely related to decision-making at Oak College, an arena where interactions are prevalent at the college. The influence of government at Oak College can be seen as a negative one: board and president are allied against government on matters which they view as threats to their collective concept of the college. These threats can be seen most prominently in the area of funding where government fiscal restraint challenged the goals of the college to increase community access to college activities and educational programmes. Government was viewed as a negative determinant of the relationship at Oak College. 
At Cedar College, determinants are numerous, and two patterns of determinants are most prevalent. One pattern includes those who fill specific roles: individuals who have influence within the college and who have impact on how the board and the president work together. These individuals are the president, the bursar, the deans, the board chairperson, and several faculty members. For example, the board chairperson is viewed as a determinant of the board-president relationship, and influence is a consequence of her long years of active service on behalf of the college, her knowledge of college governance, her leadership role with the other board members, and the close working and strong personal relationship she has with the president. The second pattern can be seen in how the parties perceive the values, traditions, and belief system of the college. This perception establishes a framework in which board and president work together. This framework can be characterized as a boundary, signifying what are and are not appropriate as behaviours and actions of board members and the president.

\section{Effects of the Relationship}

What board members and the president do together, how they interact and perceive each other, and how they and their actions are perceived both within the institution and externally have consequences. At Appletree College, the relationship is perceived by the parties to have enhanced the image of the college in the community, to have established harmony within the college, and to have gained support and approval from government for both the college and for the management of the college. At Oak College, effects of the relationship are perceived primarily as affective, involving the feelings and attitudes of both college personnel and community members. The emphasis upon open communications and participation in decision-making by the two parties is seen to reinforce behaviours and lead to results. At Cedar College, the major dominant effect perceived by the two parties is the relationship's contribution to the maintenance of the status quo, particularly with regard to the philosophy and values held by college constituents.

\section{How Do Boards and Presidents Work Together? (the enterprise, the family, and the corporate academy)}

Board and president together are structural components of the institution; as chief authorities in decision-making, they occupy the "strategic apex" (Mintzberg, 1983) of the organization. They are also participants within the 
institution in such processes as policy development, budget development, educational planning, and creation of a public image for the college. They project in how they work together what can be referred to as the corporate culture (Deal \& Kennedy, 1982) of their college. The values expressed by board members and presidents reflect the goals of their respective colleges, and their style of operation together is consistent with the images the parties use to describe their respective colleges.

At Appletree College, the character of the board-president relationship was formed out of a past, under a former presidency, highlighted by excessive presidential control, financial problems, and a public scandal. Whereas the board is repelled by this past and the accompanying events, the president is seen as the obverse of the past's negative image. The further the college moves away from association with this past, and with the former president, the greater the satisfaction for board members and the greater the reinforcement for the president and his actions. With the board's support, the president is seen to have rescued the college from infamy by pursuing dramatic change in a pragmatic fashion. The college is present and future oriented: highly sensitive to the public and market oriented in its approach to operations. In order to maintain this market orientation, board and president have developed a pattern of behaviours and decision-making which places them at the apex of the organization as chief authority figures. Formally, the board allows the president to direct and control the operations of the college (with his administrative group). The actions of the president, however, are constrained by both board approval and by specific directions especially from the board chairperson. Through the way the parties work together, the college has been able to present consistent and uniform responses and images of the college to the public and to government. Through the combined actions of board and president, the reputation of Appletree College has improved externally and the reputations of both the president and the board have improved internally. Not only has the college survived, it has secured needed resources and flourished reputationally. The entrepreneurial image of the college matches the operating style of board and president in how they work together to govern and manage the college.

At the centre of the board-president relationship at Oak College is a concept of the college as a family or commune which functions through co-operation, consensus, and emphasis upon the external community served by the college. The board-president relationship is viewed by the two parties as secondary to the college. The rationales and justifications for what board members and president do together have their basis in the values and history of the college. Policies, for example, are seen as collective efforts, the result of the evolution of 
the college. Through their approach to governance and their managerial activities, board and president together ensure that both college students and the external community members have the benefits of college services. Consistent with the concept of communal decision-making, board and president share their responsibilities, and broad constituent participation in institutional decisionmaking is encouraged by the two parties.

At Cedar College, there is evident conformity in attitudes, behaviours, and actions of board and president to the values and philosophy of the college. This conformity serves to reinforce values and the philosophy of the institution. Therefore, the relationship can be seen to be sustained by, and to sustain, the ethos of the college. This self-perpetuated image of Cedar College justifies how board and president work together, what they do, and the consequences of their behaviours and actions. Board and president work together within the larger context of college beliefs (e.g., that the college is an elite institution) and the college's philosophy. The college philosophy arises not from the mandate of government legislation or from externally driven or market values, but from both the traditions of the college and the particular attitudes and actions of internal constituents, mainly faculty and a few administrators. The president of Cedar College noted that there is a pervasive conscience within the institution, and a board member asserted that a change in presidents would have no effects on the philosophy of the college. Decisions by college constituents, including board and president, are expected, and believed, to conform to identified traditions and values of the college and its internal constituents. A corporate model of governance, with the board in the role of formal approvers and the president in the role of operational and executive leader, is used in conjunction with a professional bureaucratic management style (Mintzberg, 1983) to direct a college with an elite self-image. The college as academy is an image sustained by and reflected in the operations of the board and the president.

As a unit of the larger organization, board and president together both mirror and sustain distinguishing features of their institutions. At Appletree College, board and president together in their behaviours and attitudes exhibit the influence that the events of the past and the behaviours of the former president had upon their college. At Oak College, board and president display in their behaviours the participatory, co-operative style of the larger institution. And at Cedar College, board and president in their decisions demonstrate allegiance to a college philosophy held by internal college constituents. 


\section{Implication of the Importance of the Relationship}

While the purpose of this study is to examine the board-president relationship and to explain why the relationship has importance, the descriptive nature of the study does not lead directly to evaluations or judgements of the quality of boardpresident relationships. Conclusions from this study, articulated near the outset of this article, are silent on such issues as effective or ineffective relationships and conflict within the relationship. Nonetheless, the study has led to several implications derived from the study's findings and conclusions.

In what ways the academic institution is governed and managed, and with what accompanying behaviours by those who are responsible, have been underlying questions for those who study the academic institution. On a more practical and mundane level, those who govern and manage the academic institution, as well as those who work within colleges, technical institutes, and universities, may want to know why some institutions seem to be managed well and others poorly, why there is tension and strife at one college but not at another, why some presidents resign and others endure, and why some governing boards are more effective than others. How the governing board and president work together and the reasons for the importance of the boardpresident relationship in the three community colleges in this study may suggest one way of addressing these issues.

In their appeals for improvement for higher education, scholars have focussed upon management and the requirements of leadership to rescue colleges and universities from dysfunctional paths or even collapse. Keller (1983) has urged increased institutional productivity, claiming that colleges and universities are poorly managed. Austin (1985) has advocated improved student performance, suggesting that colleges and universities ignore student learning. Others (Campbell \& Associates, 1985; Dennison \& Gallagher, 1986) promote greater organizational adaptability, indicating that institutions which characterize themselves as responsive to external demands and needs are too traditional and not flexible. The principal outcomes of the board-president relationship at the three community colleges identified in this study sit in a contrasting light to the expectations of scholars for improvements in academic management. The emphasis of board and president in working together in the three colleges of this study is upon both the external image of the college and internal harmony among constituent groups. Institutional productivity, improvements in student learning, and organizational adaptability are not among the priorities on the agenda for the two parties to the board-president relationship. 
Instead of these substantive outcomes (e.g., improvements in student learning), what board and president do together to govern and manage the academic institution can be referred to as symbolic action (Pfeffer, 1981) which leads to symbolic, or intangible, results. The parties engage in the creation and management of the meaning that both the public and internal constituents attribute to the college and its outcomes. This suggests that leadership questions about institutional performance in higher education may be misdirected. From one perspective, that which evaluates tangible results, the actors in academic institutions (especially those in positions of formal authority) do not accomplish what scholars promote (e.g., student learning improvements, greater institutional productivity). From another perspective, that which describes effects upon internal and external interest groups and college participants, administrative behaviours in higher education (and leadership) generate symbolic results, or a reality that is socially constructed.

These administrative behaviours may indeed produce significant, but not tangible, accomplishments. Thus, those who manage well, those who lead institutions without tension or strife, and those who endure as leaders are not those who produce quantifiable outcomes, such as increased enrolments or new facilities, but rather those who fulfil the aspirations of interest groups, those who act in accord with college traditions and who can understand and interpret college history, and those who accept and reinforce the values held by internal constituents. The outcomes of these behaviours and actions are not tangible but they can be perceived. And, the more widely and intensely are perceptions held about an institution, the less likely it may be to discriminate between substantive and symbolic actions. The absence of symbolic outcomes, such as improved faculty morale, encouragement of broad constituent participation in decision-making, or the maintenance of college philosophy, even with the presence of tangible products such as ever increasing student numbers, may indicate why there are adverse relations between board and president (Cleary, 1979), why there are undercurrents in the relationship (Wood, 1984), and why presidents have problems with boards.

Not only are there reasons for the importance of the board-president relationship in the academic institution but, also, these reasons give us insight into the function and significance of administrative behaviours in colleges and universities. These behaviours may help to influence or, indeed, shape institutional functioning or they may be reflections of that functioning. Board and president as a unit may be susceptible to the public's negative image of the college and to internal fractiousness. Such conditions may lead to boardpresident tensions and, as a consequence of the ascribed leadership position of 
presidents, to the dismissal of the chief executive officer. On the other hand, tensions and strife in the board-president relationship may be impediments to the parties' behaviours in creating and managing the meaning that interest groups, such as faculty, require to keep the institution from a dysfunctional path.

\section{REFERENCES}

Alfred, R. \& Smydra, D. (1985). Reforming governance: Resolving challenges to institutional authority. In W. Deegan \& D. Tillery (Eds.), Renewing the American Community College. San Francisco: Jossey-Bass Publishers.

Austin, A. (1985). Achieving educational excellence. San Francisco: Jossey-Bass Publishers.

Baldridge, J., Curtis, D., Ecker, G., \& Riley, G. (1977). Alternative models of governance in higher education. In G. Riley and J. Baldridge (Eds.), Governing academic organizations. Berkeley: McCutchan Publishing Corporation.

Birnbaum, R. (1988). How colleges work: The cybernetics of academic organization and leadership. San Francisco: Jossey-Bass Publishers.

Burgess, R. (1985). Strategies of educational research: Qualitative methods. London: The Falmer Press.

Cameron, K. (1984). Organizational adaptation and higher education. Journal of Higher Education, 55(2), 122-144.

Campbell, D. \& Associates (1985). Leadership strategies for community college effectiveness. Washington, D.C.: American Association of Community and Junior Colleges.

Clark, B. (1983). The higher education system. Academic organization in cross-national perspective. Berkeley: University of Califomia Press.

Cleary, R. (1979). Trustee-president authority relations. Educational Record, $\underline{60}(1), 146-$ 158.

Corson, J. (1975). The governance of colleges and universities. New York: McGraw-Hill.

Corson, J. (1980). Participating in policy making and management. In R. Ingram \& Associates (Eds.), Handbook of college and university trusteeship. San Francisco: Jossey-Bass Publishers.

Deal, T. \& Kennedy, A. (1982). Corporate cultures: The rites and rituals of corporate life. Don Mills, Ontario: Addison-Wesley Publishing Company.

Dennison, J. (1986). Some aspects of government policy towards community colleges in British Columbia: 1982-86. Journal of Educational Administration and Foundations.

Dennison, J. \& Gallagher, P. (1986). Canada's community colleges. Vancouver: University of British Columbia Press.

Dill, D. (1984). The nature of administrative behavior in higher education. Educational Administration Quarterly, 20 (3), 69-99.

Erickson, F. (1986). Qualitative methods in research on teaching. In M. Wittrock (Ed.), Handbook of research on teaching. New York: MacMillan Publishing Company.

Fisher, J. (1984). Power of the presidency. New York: MacMillan Publishing Company.

Gleazer Jr., E. (1985). Governance and the shifting role of the board of trustees. In W. Deegan \& J. Gollattscheck (Eds.), New directions for community colleges: Ensuring effective governance. San Francisco: Jossey-Bass Publishers. 
Goetz, J. \& Le Compte, M. (1984). Ethnography and qualitative design in educational research. Orlando: Academic Press.

Hammersley, M. \& Atkinson, P. (1983). Ethnography: Principles and practice. London: Tavistock Publications.

Ingram, R. (1979). The marriage of presidents and boards. In R. Lahti (Ed.), New directions for community colleges: Managing in a new era. San Francisco: JosseyBass Publishers.

Kaplin, W. (1985). The law of higher education. San Francisco: Jossey-Bass Publishers.

Kauffman, J. (1980). At the pleasure of the board. Washington, D.C.: American Council on Education.

Keller, G. (1983). Academic strategy: The management revolution in American higher education. Baltimore: The Johns Hopkins University Press.

Kerr, C. \& Gade, M. (1986). The many lives of academic presidents. Washington, D.C.: Association of Governing Boards of Universities and Colleges.

Lee, S. \& Van Horn, J. (1983). Academic administration. Lincoln, Nebraska: University of Nebraska Press.

Levin, J. (1989). The board-president relationship in three British Columbia community colleges. Unpublished doctoral dissertation. Vancouver, B.C.: University of British Columbia.

Merriam, S. (1988). Case study research in education. San Francisco: Jossey-Bass Publishers.

Miles, M. \& Huberman, A. Qualitative data analysis. Beverly Hills: Sage Publishing.

Mintzberg, H. (1983). Structure in fives. Englewood-Cliffs, New Jersey: Prentice Hall Inc.

Mortimer, K. \& McConnell, T. (1978). Sharing authority effectively. San Francisco: Jossey-Bass Publishers.

Munitz, B. (1980). Reviewing presidential leadership. In R. Ingram \& Associates (Eds.), Handbook of college and university trusteeship. San Francisco: Jossey-Bass Publishers.

Pappas, R. \& Ritter, S. (1983). Survey finds administrators, trustees differ on roles. Community and Junior College Journal, 54 (2), 18-19.

Pfeffer J. (1981). Management as symbolic action: The creation and maintenance of organizational paradigms. Research in organizational behavior, 3, 1-52.

Popkewitz, T. (1984). Paradigm and ideology in educational research. The Falmer Press.

Province of British Columbia, (1984). College and institute Act. Victoria: Queens Printer.

Richardson Jr., R., Blocker, C., \& Bender, L. (1972). Governance for the two year college. Englewood Cliffs, New Jersey: Prentice-Hall.

Smith, J. (1983). Quantitative versus qualitative research: An attempt to clarify the issue. Educational Researcher, March, 6-13.

Vaughan, G. (1986). The community college president. New York: American Council on Education and MacMillan Publishing.

Wood, M. (1984). Crosscurrents and undercurrents in the trustee-president relationship. Educational Record, 65 (1), 38-42.

Wood, M. (1985). Trusteeship in the private college. Baltimore: The Johns Hopkins University Press. 